\title{
Säilörehun ja koko rehuannoksen syönti-indeksit auttavat lypsylehmien ruokinnan suunnittelussa
}

\author{
Marketta Rinne $^{1)}$, Pekka Huhtanen ${ }^{1,2)}$ ja Juha Nousiainen ${ }^{3)}$ \\ ${ }^{1)}$ MTT, Kotieläintuotannon tutkimus, 31600 Jokioinen, etunimi.sukunimi@mtt.fi \\ ${ }^{2)}$ Cornell University, Department of Animal Science, 269 Morrison Hall, Ithaca, NY 14853-4801, USA \\ ${ }^{3)}$ Valio Oy, Alkutuotanto, PL 10, 00039 Valio, etunimi.sukunimi@valio.fi
}

\section{Tiivistelmä}

Rehujen vapaaehtoisen syönnin arviointi on yksi ruokinnansuunnittelun tärkeimmistä asioista, koska syönnin vaihtelu on erittäin suurta. Se vaikuttaa lehmien ravintoaineiden saannin vaihteluun huomattavasti enemmän kuin esimerkiksi rehujen sulavien ravintoaineiden pitoisuuden vaihtelu. Rehujen vapaaehtoisen syönnin määrään vaikuttavat eläimen, ympäristön, rehuannoksen ja yksittäisten rehujen ominaisuudet ja näiden tekijöiden yhdysvaikutukset. Tässä artikkelissa esitetään ns. Tuotosvasteaineistoon perustuen suhteelliset säilörehun ja koko rehuannoksen syönti-indeksit, joiden perusteella voidaan arvioida säilörehun laadun sekä väkirehuruokinnan määrän ja laadun vaikutuksia rehujen syönnin suhteelliseen muutokseen tilanteissa, joissa ruokinta perustuu vapaaseen säilörehun syöttöön tai seosrehuruokintaan.

Säilörehun syönti-indeksi suurenee, kun säilörehun sulavuus (D-arvo) suurenee ja käymislaatu paranee (kokonaishappojen pitoisuus pienenee). Kuiva-ainepitoisuuden vaikutus on käyräviivainen siten, että syönti on suurimmillaan kun säilörehun kuiva-ainepitoisuus on n. 420 g/kg KA. Ensimmäisen sadon rehua syödään enemmän kuin koostumukseltaan samanlaista mutta jälkisadosta tehtyä rehua. Palkokasveja tai kokoviljasäilörehua sisältävän säilörehun vapaaehtoinen syönti on suurempi kuin pelkistä nurmiheinistä tehdyn koostumukseltaan vastaavan säilörehun. Vaikutukset ovat käyräviivaisia ja yhtälöitä kannattaa käyttää siten, että korkeintaan puolet säilörehun kuiva-aineesta on muita kasvilajeja myös tilanteissa, joissa niiden pitoisuus todellisuudessa on suurempi.

Väkirehuannoksen suurentaminen vähensi säilörehun vapaaehtoista syöntiä siten, että korvaussuhde [vapaasti syötetyn säilörehun syönnin väheneminen, kun väkirehun saantia lisätään ( $\mathrm{kg} \mathrm{KA} / \mathrm{kg}$ KA)] oli keskimäärin 0.47. Korvaussuhde ei kuitenkaan ollut lineaarinen vaan säilörehun syönti vähentyi enemmän kun väkirehuannokset olivat suuria. Väkirehun valkuaispitoisuuden suureneminen lisäsi säilörehun syöntiä käyräviivaisesti, mutta valkuaisen hajoavuuden lisääntyminen vähensi sitä. Väkirehun kuitupitoisuuden suureneminen lisäsi, mutta rasvapitoisuuden suureneminen vähensi säilörehun vapaaehtoista syöntiä. Väkirehun energiapitoisuuden muutokset lehmien energian saantiin ovat siis vapaalla säilörehuruokinnalla odotettua vähäisempiä.

Yhdistämällä säilörehun ja väkirehun syönti-indeksit voidaan arvioida koko rehuannoksen syöntipotentiaali. Säilörehun ja koko rehuannoksen syönti-indeksejä voidaan hyödyntää kun arvioidaan, miten paljon rehuannoksen syönti muuttuu sen koostumusta muutettaessa. Säilörehuerän vaihtamisen yhteydessä voidaan syönti-indeksejä tarkastelemalla valita väkirehuannos siten, että kokonaissyönti ja maitotuotos pysyvät halutulla tasolla. Syönti-indeksien laskemiseen on Artturi-verkkopalvelussa (www.mtt.fi/artturi) käytettävissä laskurit. Rehuannoksen koostumuksen vaikutusten tunteminen lehmien vapaaehtoiseen syöntiin tekee mahdolliseksi lehmien ravintoaineiden saannin ja maidontuotannon mallintamisen ja mallien käytön ruokinnan optimoinnissa. Kun rehuannoksen vaikutukset syöntiin on mallinnettu, on jatkotutkimuksissa mahdollista selvittää eläintekijöiden vaikutusta syöntiin.

Asiasanat: Säilörehu, väkirehu, ruokinta, lypsylehmä, vapaaehtoinen syönti, korvaussuhde 


\section{Johdanto}

Rehujen ravintoainepitoisuudet ja lypsylehmien ravintoaineiden tarve ovat varsin hyvin tunnettuja, mutta rehujen vapaaehtoisen syönnin arviointi on vaikeaa. Se on kuitenkin yksi ruokinnansuunnittelun tärkeimmistä asioista, koska syönnin vaihtelu on erittäin suurta ja se vaikuttaa lehmien ravintoaineiden saannin vaihteluun huomattavasti enemmän kuin esimerkiksi rehujen sulavien ravintoaineiden pitoisuuden vaihtelu (Mertens 1994).

Rehujen vapaaehtoisen syönnin määrään vaikuttavat eläimen, ympäristön, rehuannoksen ja yksittäisten rehujen ominaisuudet ja näiden tekijöiden yhdysvaikutukset. Eläimen ominaisuuksia ovat $\mathrm{mm}$. koko, rotu, perinnöllinen maidontuotantokyky ja lypsykauden vaihe. Riittävä tarjolla olevan rehun määrä, syömiseen käytettävissä oleva aika ja tila sekä kaikki muut eläinten hoitoon liittyvät yksityiskohdat yksittäisillä tiloilla ovat merkittäviä syöntiin vaikuttavia ympäristötekijöitä. Rehuannoksen ja rehujen ominaisuuksia ovat väkirehun osuus, väkirehun koostumus, karkearehun sulavuus, käymislaatu jne.

Tässä artikkelissa esitetään ns. Tuotosvasteaineistoon perustuen suhteelliset säilörehun ja koko rehuannoksen syönti-indeksit, joiden perusteella voidaan arvioida säilörehun laadun sekä väkirehuruokinnan määrän ja laadun vaikutuksia rehujen syönnin suhteelliseen muutokseen tilanteissa, joissa ruokinta perustuu vapaaseen säilörehun syöttöön tai seosrehuruokintaan. Syönnin ennustamisessa ei käytetä tietoa lehmien tuottamasta maitomäärästä. Kuiva-aineen kokonaissyönti selitti Tuotosvasteaineistossa 95 \% maidontuotannon vaihteluista kokeiden sisällä, joten maitomäärän avulla voidaan rehujen syönti ennustaa varsin tarkasti. Toisaalta muutokset rehuannoksen ja yksittäisten rehujen koostumuksessa vaikuttavat maitotuotokseen, joten rehujen itsenäistä vaikutusta syöntiin ei täten pystytä arvioimaan. Tämän takia valitsimme lähtökohdaksi rehuperäisten tekijöiden vaikutusten arvioinnin rehujen suhteelliseen syöntipotentiaaliin.

Säilörehun syönti-indeksin ensimmäinen versio julkaistiin v. 2002 (Huhtanen ym. 2002). Tässä työssä käytetään samaa lähestymistapaa, mutta nyt on analysoitu laajempi ja monipuolisempi aineisto. Säilörehun sulavuuden ja käymislaadun lisäksi nyt pystytään huomioimaan kuiva-ainepitoisuuden, sadon (1. sato vs. jälkisato) ja kasvilajikoostumuksen vaikutukset säilörehun syöntipotentiaaliin. Lisäksi huomioidaan väkirehuruokinnan vaikutukset säilörehun ja siten koko rehuannoksen syöntiin. Aineisto, menetelmät ja laajempi tulosten pohdinta on saatavilla tieteellisissä artikkeleissa (Huhtanen ym. 2007a,b).

\section{Aineisto ja menetelmät}

Tuotosvasteaineisto sisältää tiedot 998 ruokinnan vaikutuksista lypsylehmien rehujen syöntiin. Aiemmin suoritetuista maidontuotantokokeista on kerätty tiedot rehuannoksesta ja rehujen syönnistä. Mukaan otettiin kokeita, joissa säilörehua syötettiin vapaasti. Kaikkiaan aineistossa on mukana 207 koetta, joista noin puolet on suomalaisia ja loput pääasiassa Isosta Britanniasta. Irlannista ja Skandinaviasta on lisäksi mukana muutamia kokeita.

Säilörehun laadun vaikutusta syöntiin selvitettiin osa-aineistojen perusteella, joissa oli tutkittu säilörehun D-arvon (nurmikasvien kehitysvaihe korjuuhetkellä, ruokintojen lukumäärä eli $n=81$ ), käymislaadun (säilöntäaineen vaikutus, $n=240$ ), kuiva-ainepitoisuuden (esikuivaus, $n=85$ ), sadon (ensimmäinen niitto vs. jälkisato, $n=46)$ ja palkokasvien $(n=53)$ tai kokoviljasäilörehun $(n=37)$ osuuden vaikutusta säilörehun syöntiin. Väkirehuruokinnan osalta tarkasteltiin väkirehuannoksen määrää $(n=217)$, valkuaistäydennystä $(n=336)$ ja tärkkelyspitoisten väkirehukomponenttien korvaamista kuitupitoisilla raaka-aineilla $(\mathrm{n}=114)$ tai rasvalla $(\mathrm{n}=29)$.

Osa-aineistot analysoitiin erikseen sekamalliregressioanalyysillä (SAS Mixed Model) ja regressiokertoimet yhdistettiin olettaen, että ne ovat additiivisia eli suoraan yhteenlaskettavissa. Väkirehun syönti-indeksissä huomioitiin lisäksi väkirehuruokinnan ja säilörehun syönti-indeksin yhdysvaikutus.

\section{Tulokset ja niiden tarkastelu}

\section{Säilörehun syönti-indeksi}

Säilörehun syönti-indeksin laskemiseksi saatiin seuraava kaava: 
Säilörehun syönti-indeksi $=100+10 \times$

[(D-arvo -680$) \times 0.017$

- (hapot -80$) \times 0.0128$

$+\left(0.0198 \times(\mathrm{KA}-250)-0.00002364 \times\left(\mathrm{KA}^{2}-250^{2}\right)\right)$

$-0.44 \times$ jälkisatosäilörehun osuus

$+4.13 \times$ palkokasvien osuus $-2.58 \times$ palkokasvien osuus ${ }^{2}$

$+5.90 \times$ kokoviljasäilörehun osuus $-6.14 \times$ kokoviljasäilörehun osuus $^{2}$

$-0.0023 \times($ kuitu-550)],

jossa jälkisato-, palkokasvi- ja kokoviljasäilörehujen osuus vaihtelee välillä 0-1, D-arvo on säilörehun sulavan orgaanisen aineen pitoisuus (g/kg KA), hapot on käymishappojen yhteismäärä eli maitohappo + haihtuvat rasvahapot (g/kg KA), KA on säilörehun kuiva-ainepitoisuus (g/kg) ja kuitu on säilörehun neutraalidetergenttimenetelmällä määritetty kuitupitoisuus (g/kg KA). Indeksi lasketaan siten, että rehua verrataan standardisäilörehuun, jonka ominaisuudet ovat seuraavat: D-arvo $680 \mathrm{~g} / \mathrm{kg} \mathrm{KA}$, hapot 80 g/kg KA, KA-pitoisuus 250 g/kg, kuitupitoisuus 550 g/kg KA, tehty 1. sadosta, ei sisällä palkokasveja eikä kokoviljasäilörehua.

Taulukossa 1 on havainnollistettu säilörehun ominaisuuksien vaihtelun aiheuttamia muutoksia säilörehun syönti-indeksiin. Indeksi ei kerro sitä, kuinka paljon lehmät todellisuudessa syövät rehua, vaan sen, kuinka paljon syönti muuttuu, jos säilörehun ominaisuudet muuttuvat. Yleistäen voidaan ajatella, että jos lehmä syö 100 indeksipistettä saanutta rehua $10 \mathrm{~kg} \mathrm{KA} / \mathrm{pv}$, sen säilörehun syönti muuttuu 0.1 kg KA, kun säilörehun syönti-indeksi muuttuu yhden pisteen.

Indeksin mukaan säilörehun kuiva-aineen syönti lisääntyy 0.17 kg päivässä, kun D-arvo lisääntyy 10 g/kg KA ja vähenee 0.128 kg, kun käymishappojen pitoisuus lisääntyy 10 g/kg KA.

Kuvassa 1 on esitetty säilörehun kuiva-ainepitoisuuden vaikutus säilörehun syönti-indeksiin. Vaikutus on käyräviivainen siten että syönti on korkeimmillaan, kun säilörehun kuiva-ainepitoisuus on 420 g/kg. Tällöin säilörehun syönti-indeksi on noin 6 pistettä korkeampi kuin muuten koostumukseltaan samanlaisen mutta 250 g kuiva-ainetta kilossa sisältävän rehun. Rehun vapaaehtoisen syönnin voi tällöin arvioida olevan 0.6 kg KA päivässä suurempi. Aineistossa oli varsin vähän säilörehuja, joiden kuiva-ainepitoisuus oli yli $500 \mathrm{~g} / \mathrm{kg}$, joten pitkälle esikuivattujen säilörehujen ennusteet ovat varsin epävarmoja. Päädyimme käyttämään välillä 500 - $850 \mathrm{~g} / \mathrm{kg}$ lineaarisesti laskevaa yhteyttä siten että kuivan heinän kuiva-ainepitoisuudessa syönti-indeksi saavuttaa saman arvon kuin säilörehussa, jonka kuiva-ainepitoisuus on $250 \mathrm{~g} / \mathrm{kg}$ KA. Tämä perustuu kokemukseen että jos samasta kasvustosta tehdään esikuivaamatonta säilörehua tai väkiheinää, ei rehujen syöntimäärissä ole eroja.

Kesän ensimmäisestä sadosta tehdyn säilörehun syönti on yksittäisten tutkimusten (mm. Kuoppala ym. 2007) ja käytännön tuntuman perusteella suurempi kuin loppukesällä nurmen jälkisadosta tehdyn säilörehun syönti. Tämän aineiston perusteella jälkisatosäilörehun syönti-indeksi on 4.4 pistettä eli n. $0.44 \mathrm{~kg} \mathrm{KA} / \mathrm{pv}$ pienempi kuin koostumukseltaan vastaavan mutta ensimmäisestä sadosta tehdyn säilörehun.

Palkokasvien ja kokoviljasäilörehun osuuden lisääntyminen säilörehussa vaikuttavat käyräviivaisesti säilörehun syönti-indeksiin (kuva 2). Havaintoja on varsin vähän rehuista, joissa palkokasvien ja kokoviljasäilörehun osuus ylittää puolet säilörehun kuiva-aineesta. Tällaiset ruokinnat ovat myös käytännössä lypsylehmien ruokinnassa harvinaisia. Yhtälöitä kannattaa käyttää siten, että korkeintaan puolet säilörehun kuiva-aineesta on muita kasvilajeja myös tilanteissa, joissa niiden pitoisuus todellisuudessa on suurempi. Puolet puna-apilaa ja kokoviljasäilörehua sisältävän seoksen syönti-indeksi on n. 14 pistettä korkeampi kuin muuten koostumukseltaan vastaavan pelkistä nurmiheinäkasveista tehdyn säilörehun. Rehun syönti on siis lähes 1.5 kg KA päivässä suurempi, jos rehut muiden syöntiindeksissä huomioitujen ominaisuuksien osalta ovat samanlaisia.

Luotettavan syöntiarvion tekemiseksi puna-apilapitoisesta säilörehusta tarvitaan tieto punaapilan osuudesta rehussa. Arvio voidaan tehdä nurmikasvustosta silmämääräisesti tai erottelemalla käsin puna-apila ja nurmiheinät toisistaan. Silmämääräinen arvio ei ole kovin luotettava. Erotteluun perustuva menetelmä on työläs ja vaatii näytteenotolta huomattavaa huolellisuutta, koska kasvilajien osuudet vaihtelevat huomattavasti pellon eri kohdissa. Puna-apilan kalsiumpitoisuus on huomattavasti nurmiheiniä korkeampi, joten myös sitä voidaan käyttää nurmikasvuston tai säilörehun apilapitoisuuden arvioimiseen (Rinne ym. 2008). 
Käytännössä nurmi- ja kokoviljasäilörehut tehdään erikseen ja sekoitetaan vasta ruokinnan yhteydessä. Kokoviljasäilörehun vaikutus rehuseoksen syöntiin voidaan huomioida sen perusteella, kuinka suuren osuuden säilörehun kokonaismäärästä se muodostaa. Muiden ominaisuuksien kuten D-arvon ja käymishappojen osalta on laskettava käytettyjen säilörehujen painotettu keskiarvo.

Säilörehun kuitupitoisuudella oli itsenäinen muista ominaisuuksista riippumaton vaikutus syöntiin, mutta numeerisesti se oli pieni. Jos säilörehun kuitupitoisuus pienenee 550:stä 450 g:an /kg KA, syönti-indeksipisteet lisääntyvät 0.23:lla ja säilörehun syönti siis n. 0.023 kg KA/pv.

Säilörehun syönti-indeksin laskenta edellyttää sitä, että käytettävissä on luotettavat lähtötiedot säilörehun ominaisuuksista. Säilörehun sulavuuden merkitys indeksissä on suuri ja sulavuuden määrittäminen on varsin haasteellista. Nykyisin käytettävissä olevilla tutkimus- ja rutiinimenetelmillä sulavuus voidaan kuitenkin kohtuullisen luotettavasti arvioida (Huhtanen ym. 2006, Huhtanen ym. 2008a). D-arvo ja tarvittavat säilörehun koostumustiedot sisältyvät Valio Oy:n Artturi-rehuanalyysiin ja tässä kirjoituksessa kuvattu syönti-indeksi myös tulostetaan rehuanalyysin tulosten mukana. Jotta säilörehun syönti-indeksi voidaan rehuanalyysin yhteydessä laskea oikein, täytyy rehunäytteen saatekortissa laboratorioon ilmoittaa tieto rehun sadosta (1. sato tai jälkisato) ja rehun mahdollisesti sisältämän apilan osuudesta rehun kuiva-aineessa.

Artturi-verkkopalvelussa (Artturi 2007) on käytettävissä laskuri, johon lähtötiedot voi tallentaa säilörehun syönti-indeksin laskemiseksi. Laskuria voi käyttää havainnollistamaan säilörehun laadun muutoksia rehun syöntipotentiaaliin tai tarkentamaan oman säilörehunäytteen syönti-indeksiä, jos esimerkiksi tiedot sadosta tai apilan osuudesta poikkeavat saatekorttiin merkityistä.

Taulukko 1. Laskennallinen esimerkki säilörehun ominaisuuksien vaikutuksesta säilörehun syöntiindeksiin. Ensimmäisellä rivillä on standardisäilörehu, joka saa 100 indeksipistettä. Alemmilla riveillä on tummennetulla pohjalla osoitettu se ominaisuus, jota on muutettu standardisäilörehuun verrattuna.

\begin{tabular}{|c|c|c|c|c|c|c|c|c|}
\hline $\begin{array}{l}\text { Palko- } \\
\text { kasvit }\end{array}$ & $\begin{array}{l}\text { Koko- } \\
\text { vilja }\end{array}$ & $\begin{array}{l}\text { Jälki- } \\
\text { sato }\end{array}$ & \multirow{2}{*}{$\begin{array}{l}\text { Kuiva- } \\
\text { aine, } \\
\text { g/kg }\end{array}$} & D-arvo & Наро & Kuitu & \multicolumn{2}{|c|}{$\begin{array}{c}\text { Säilörehun } \\
\text { syönti-indeksi }\end{array}$} \\
\hline \multicolumn{3}{|c|}{ Osuus } & & \multicolumn{3}{|c|}{ g/kg KA } & $2002^{1)}$ & $2007^{2)}$ \\
\hline 0 & 0 & 0 & 250 & 680 & 80 & 550 & 100.0 & 100.0 \\
\hline 0.5 & 0 & 0 & 250 & 680 & 80 & 550 & 100.0 & 114.2 \\
\hline 0 & 0.5 & 0 & 250 & 680 & 80 & 550 & 100.0 & 114.2 \\
\hline 0 & 0 & 1 & 250 & 680 & 80 & 550 & 100.0 & 95.6 \\
\hline 0 & 0 & 0 & 350 & 680 & 80 & 550 & 100.0 & 105.6 \\
\hline 0 & 0 & 0 & 250 & 640 & 80 & 550 & 93.9 & 93.2 \\
\hline 0 & 0 & 0 & 250 & 680 & 120 & 550 & 95.7 & 94.9 \\
\hline 0 & 0 & 0 & 250 & 680 & 80 & 450 & 100.0 & 102.3 \\
\hline
\end{tabular}

${ }^{1)}$ Huhtanen ym. $2002 \quad{ }^{2)}$ Huhtanen ym. 2007a

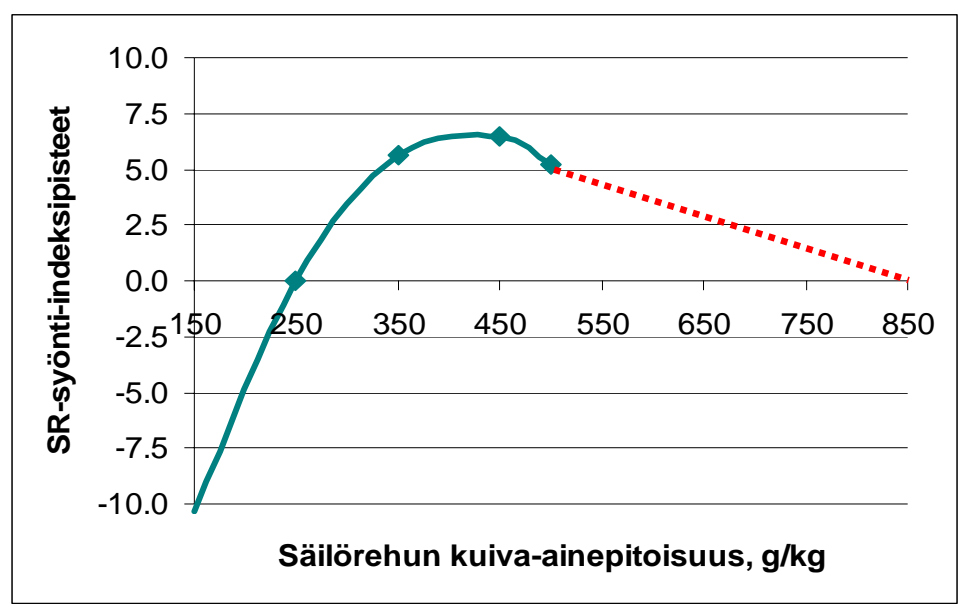

Kuva 1. Säilörehun kuiva-ainepitoisuuden vaikutus syöntipotentiaalin (SR-syönti-indeksipisteet) on käyräviivainen siten, että maksimisyönti saavutetaan, kun kuiva-ainepitoisuus on 420 g/kg KA. Kun kuiva-ainepitoisuus ylittää $500 \mathrm{~g} / \mathrm{kg}$, vaikutuksen syöntipotentiaaliin voi arvioida laskevan kuivan heinän tasolle asti suoraviivaisesti (katkoviiva). 


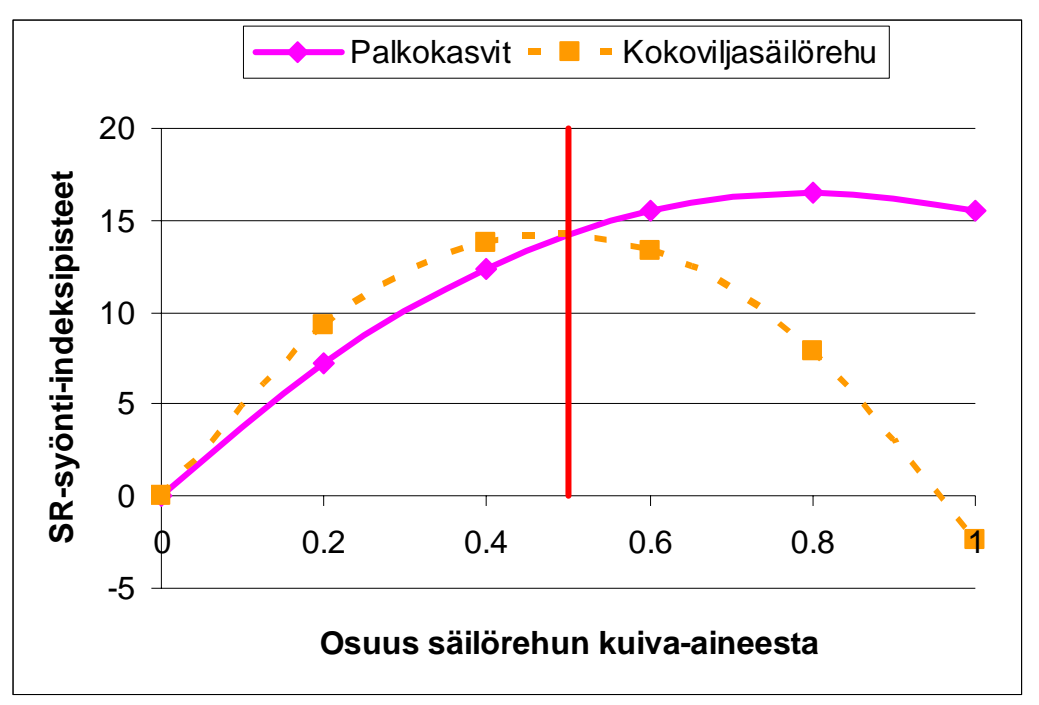

Kuva 2. Palkokasvien ja kokoviljasäilörehun osuus säilörehun kuiva-aineesta vaikuttaa säilörehun syönti-indeksiin käyräviivaisesti. Käytännössä vaikutukset kannattaa huomioida siihen asti, kun niiden osuus on puolet (0.5) säilörehun kuiva-aineesta.

\section{Väkirehun ja koko rehuannoksen syönti-indeksi}

Väkirehun määrän ja laadun vaikutukset syöntiin lasketaan seuraavasti:

Väkirehun syönti-indeksi $=100+10 \times$

[(VR-syönti - $0.1629 \times$ VR-syönti $-0.01882 \times$ VR-syönti $\left.{ }^{2}-5.49\right)$

$+\left(\left(0.9474 \times\right.\right.$ RV-saanti $-0.4965 \times$ RV-saanti $\left.{ }^{2}\right)-2.017 \times($ VR HVO -0.74$\left.)\right)$

$+0.00225 \times($ VR-kuitupit. -250$)$

$-0.0103 \times(40-$ VR-rasvapit. $)$

$-0.00058 \times($ VR-syönti - 8.0) × (säilörehun syönti-indeksi - 100)],

jossa VR-syönti on väkirehun syönti (kg KA/pv), RV-saanti on väkirehusta saatava raakavalkuainen siltä osin kuin väkirehun valkuaispitoisuus ylittää $170 \mathrm{~g} / \mathrm{kg}$ KA (kg/pv), VR HVO on väkirehun valkuaisen pötsissä hajoava osuus laskettuna väkirehukomponenttien Rehutaulukoissa (MTT 2006) ilmoitettujen HVO-arvojen painotettuna keskiarvona (g/g), VR-kuitupit. on väkirehun neutraalidetergenttimenetelmällä määritetty kuitupitoisuus (g/kg KA) ja VR-rasvapit. on väkirehun raakarasvapitoisuus (g/kg KA).

Indeksi lasketaan siten, että rehua verrataan standardiväkirehuruokintaan, jonka ominaisuudet ovat seuraavat: väkirehun syönti 8 kg KA/pv, väkirehun raakavalkuaispitoisuus 170 g/kg KA, hajoavan valkuaisen osuus $0.74 \mathrm{~g} / \mathrm{g}$, kuitupitoisuus $250 \mathrm{~g} / \mathrm{kg}$ ja rasvapitoisuus $40 \mathrm{~g} / \mathrm{kg} \mathrm{KA}$. Lisäksi mukana on väkirehun määrän ja säilörehun syönti-indeksin yhdysvaikutus. Mitä parempi säilörehun syöntiindeksi on, sitä enemmän väkirehun määrän lisääminen vähentää syöntiä. Itse väkirehun määrällä on suuri ja käyräviivainen vaikutus väkirehun syönti-indeksiin. Asiaa tarkastellaan yksityiskohtaisemmin jäljempänä kappaleessa ”Korvaussuhde”.

Väkirehun valkuaispitoisuuden lisääntyminen lisää säilörehun syöntiä käyräviivaisesti (kuva 3). Vaikutus ei johtune yksinomaan valkuaisen vaikutuksista rehuannoksen sulavuuteen vaan liittynee parempaan ravintoaineiden tasapainoon ja sitä kautta lisääntyneeseen maidontuotantoon, jolloin ravintoaineiden "imu” lisää syöntiä. Väkirehun valkuaisen pötsihajoavuuden lisääntyminen sen sijaan vähentää syöntiä (kuva 3).

Väkirehun kuitupitoisuuden suureneminen lisää, mutta rasvapitoisuuden suureneminen vähentää säilörehun vapaaehtoista syöntiä. On mielenkiintoista, että syöntiero kattaa kutakuinkin väkirehun energiapitoisuuden muutoksen molemmissa tapauksissa. Väkirehun energiapitoisuuden muutokset lehmien energian saantiin ovat siis vapaalla säilörehuruokinnalla odotettua vähäisempiä. 
Koko rehuannoksen syönti-indeksi saadaan laskemalla väkirehun ja säilörehun syönti-indeksit yhteen ja vähentämällä 100 pistettä:

Koko rehuannoksen syönti-indeksi $=$ Säilörehun syönti-indeksi + väkirehun syönti-indeksi -100

Samoin kuin säilörehun syönti-indeksin kohdalla, yhden väkirehun ja koko rehuannoksen syöntiindeksipisteen voi arvioida vastaavan noin 0.1 kuiva-ainekilon muutosta lypsylehmän päivittäisessä syönnissä.

Taulukko 2. Laskennallinen esimerkki väkirehuruokinnan ominaisuuksien vaikutuksesta väkirehun ja koko rehuannoksen syönti-indeksiin. Ensimmäisellä rivillä on standarditilanne, joka saa 100 indeksipistettä. Alemmilla riveillä on tummennetulla pohjalla osoitettu se ominaisuus, jota on muutettu standardiin verrattuna.

\begin{tabular}{|c|c|c|c|c|c|c|c|}
\hline \multirow{2}{*}{$\begin{array}{l}\text { Väkirehu- } \\
\text { annos (kg } \\
\text { KA/pv) }\end{array}$} & \multicolumn{2}{|c|}{ Valkuainen } & \multirow{2}{*}{$\begin{array}{c}\text { Valkuaisen } \\
\text { pötsihajoavuus } \\
\text { (g/g) }\end{array}$} & Kuitu & Rasva & \multicolumn{2}{|c|}{ Syönti-indeksi } \\
\hline & $\mathrm{g} / \mathrm{kg} \mathrm{KA}$ & $\mathrm{kg} / \mathrm{pv}^{1)}$ & & \multicolumn{2}{|c|}{ g/kg KA } & Väkirehu & $\begin{array}{c}\text { Koko rehu- } \\
\text { annos }^{2)}\end{array}$ \\
\hline 8 & 170 & 0 & 0.74 & 250 & 40 & 100.0 & 100.0 \\
\hline 10 & 170 & 0 & 0.74 & 250 & 40 & 110.0 & 110.0 \\
\hline 8 & 200 & 0.24 & 0.74 & 250 & 40 & 102.0 & 102.0 \\
\hline 8 & 170 & 0 & 0.64 & 250 & 40 & 102.0 & 102.0 \\
\hline 8 & 170 & 0 & 0.74 & 300 & 40 & 101.1 & 101.1 \\
\hline 8 & 170 & 0 & 0.74 & 250 & 60 & 98.0 & 98.0 \\
\hline
\end{tabular}

${ }^{1)}$ Siltä osin kuin ylittää $170 \mathrm{~g} / \mathrm{kg} \mathrm{KA}$

${ }^{2)}$ Säilörehun syönti-indeksi 100 pistettä
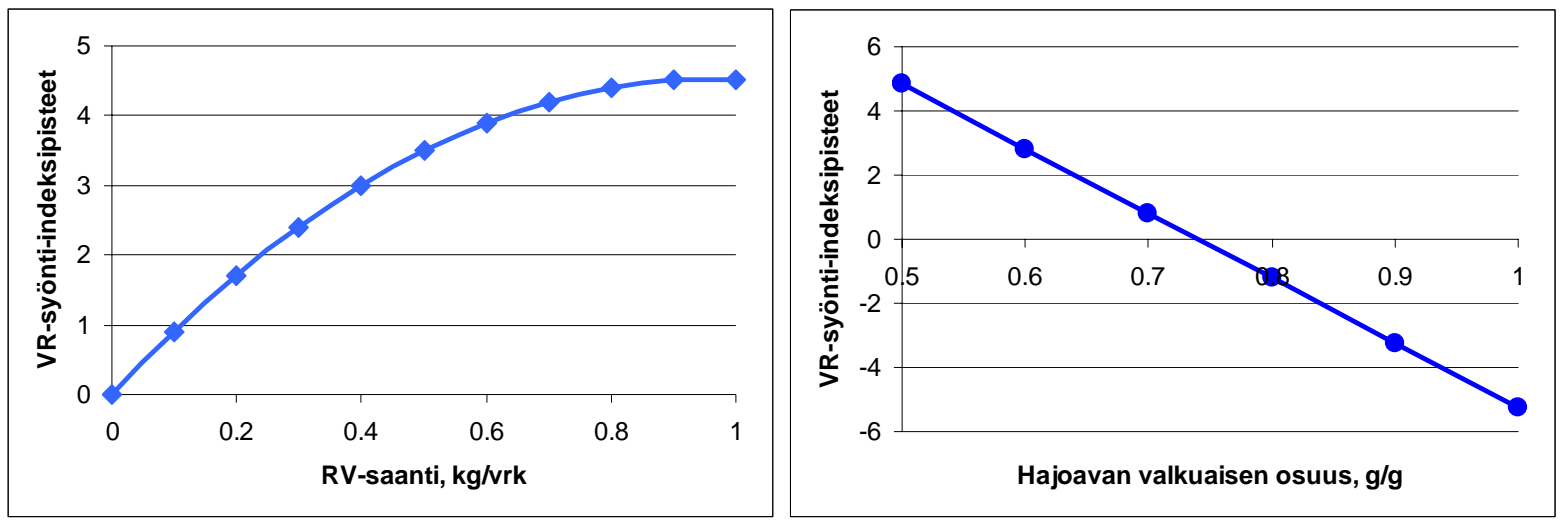

Kuva 3. Kun väkirehusta tulevan valkuaisen (yli 170 g/kg KA osalta) määrä lisääntyy, syönti lisääntyy käyräviivaisesti. Väkirehun valkuaisen pötsissä hajoavan osuuden lisääntyessä rehuannoksen syöntipotentiaali sen sijaan vähenee.

\section{Korvaussuhde}

Korvaussuhde (substitution rate) kertoo sen, kuinka paljon vapaasti syötetyn säilörehun syönti vähenee, kun väkirehun saantia lisätään (kg KA/kg KA). Korvaussuhde saadaan väkirehuannoksen ja säilörehun vapaaehtoisen syönnin lineaarisen regression kulmakertoimesta. Tässä tuotosvasteaineistossa se oli keskimäärin 0.467. Väkirehun syönti-indeksin ensimmäinen osa [(VR-syönti - $0.1629 \times$ VR-syönti - $0.01882 \times$ VR-syönti $\left.^{2}-5.49\right)$ ] kertoo korvaussuhteesta, joka ei ole lineaarinen vaan säilörehun syönti vähenee enemmän suurilla väkirehun käyttömäärillä (kuva 4). Toisaalta lehmien tuotostasolla ei ollut korvaussuhteeseen merkittävää vaikutusta. Numeerisesti syönti-indeksi suurenee 5.2 pistettä (n. 0.52 kg KA), kun väkirehuannos lisääntyy 8:sta 9 kg:aan KA, mutta vain 2.5 pistettä (n. 0.25 kg KA), kun annos kasvaa 15:stä 16 kg:an KA päivässä. 
Joissain tapauksissa korvaussuhde on ollut suurempi, kun perusrehuna käytetyn säilörehun sulavuus on ollut korkeampi (Kuoppala ym. 2007), mutta aina näin ei ole käynyt (Rinne ym. 1999). Tässä laajassa aineistossa yksittäisten säilörehun ominaisuuksien kuten D-arvon tai kuiva-ainepitoisuuden ja korvaussuhteen välillä ei löydetty merkitsevää yhteyttä. Säilörehun syönti-indeksi kokoaa useat rehun syöntipotentiaaliin vaikuttavat tekijät yhteen ja sen ja korvaussuhteen välillä oli merkitsevä yhteys. Mitä korkeampi säilörehun syönti-indeksi oli eli mitä suurempi sen syöntipotentiaali, sitä enemmän väkirehun määrän lisääminen vähensi säilörehun syöntiä (kuva 5).

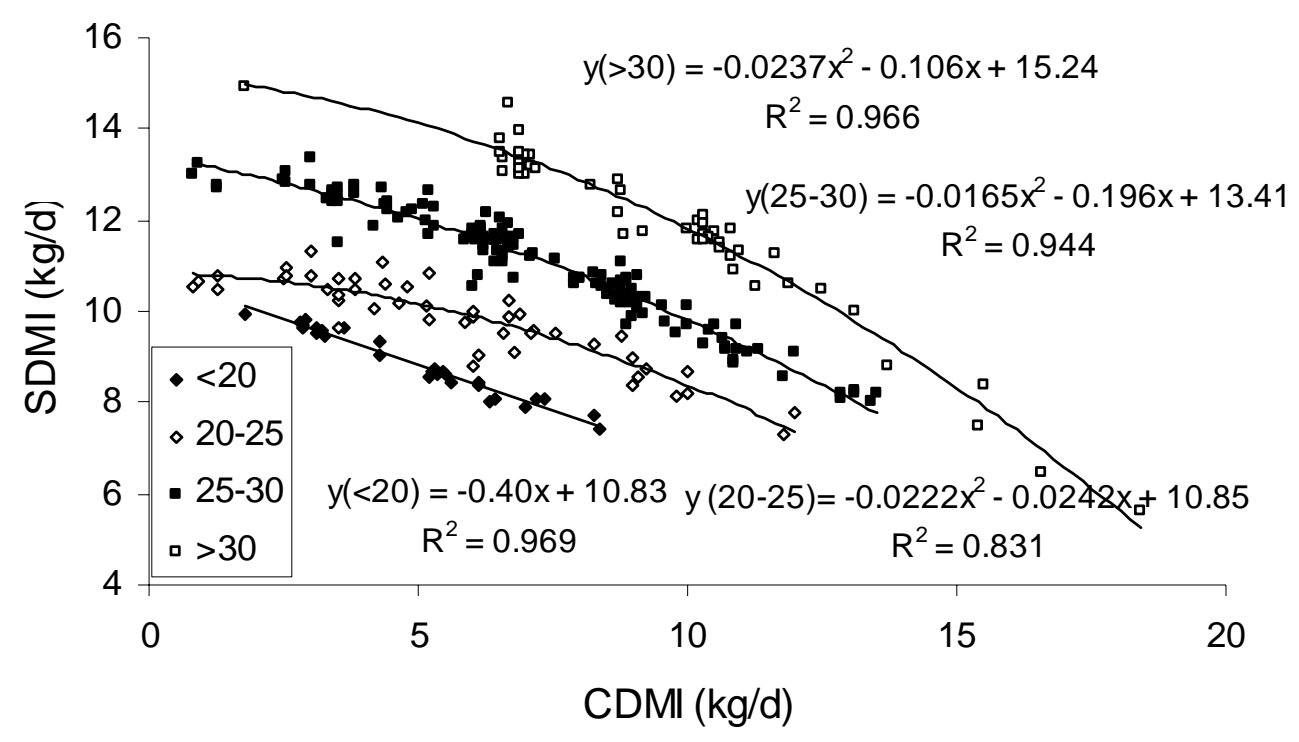

Kuva 4. Väkirehuannoksen (CDMI) suurentaminen vähensi säilörehun vapaaehtoista syöntiä (SDMI) käyräviivaisesti, mutta lehmien maitotuotoksella ei ollut yhteyteen merkittävää vaikutusta. Kuvaan on merkitty eri symboleilla tulokset kokeista, joissa vähiten lypsäneen ryhmän tuotos oli alle 20, 20-25, $25-30$ tai yli $30 \mathrm{~kg} / \mathrm{pv}$.

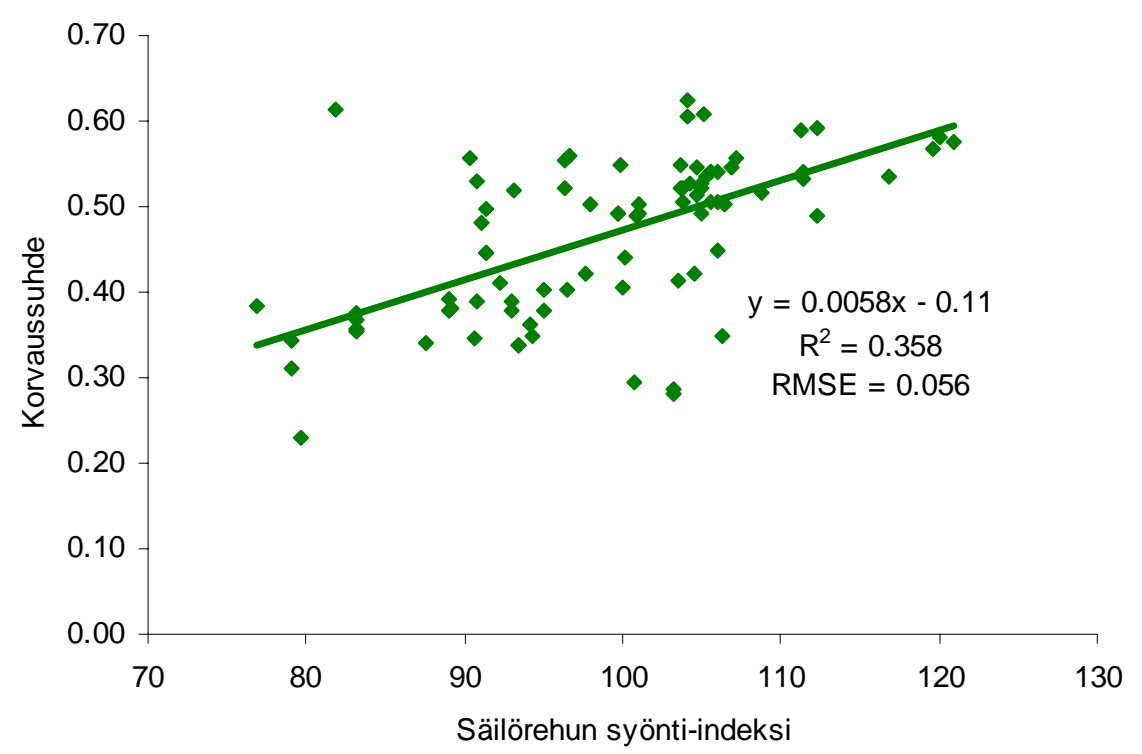

Kuva 5. Kun säilörehun syöntipotentiaali kasvaa (suurempi syönti-indeksi), myös korvausuhde (säilörehun syönnin väheneminen väkirehua lisättäessä, kg KA/kg KA) kasvaa. 


\section{Johtopäätökset}

Säilörehun ominaisuuksien ja väkirehuruokinnan vaikutukset säilörehun vapaaehtoisen syönnin ja sitä kautta koko rehuannoksen syönnin muutoksiin pystyttiin mallintamaan. Säilörehun syönti-indeksin ennustevirhe kokeen sisällä oli $0.34 \mathrm{~kg} \mathrm{KA}$. Vastaavat väkirehu- ja kokonaisindeksin virheet olivat 0.27 ja 0.37 kg KA. Suuri osa selittämättömästä vaihtelusta johtuu todennäköisesti eläinkokeiden satunnaisvaihtelusta. Muihin vastaaviin malleihin verrattuna mallin virhe oli pieni, etenkin kun ottaa huomioon sen, että muissa malleissa vasta jälkikäteen saatava maitotuotos oli usein mukana. Kokonaisindeksin testauksessa yhden pisteen vaikutus oli oletuksen mukainen eli $0.10 \mathrm{~kg} \mathrm{KA} / \mathrm{pv}$.

Säilörehun ja koko rehuannoksen syönti-indeksejä voidaan hyödyntää, kun arvioidaan miten paljon rehuannoksen syönti muuttuu koostumusta muutettaessa. Säilörehuerän vaihtamisen yhteydessä voidaan syönti-indeksejä tarkastelemalla valita väkirehuannos siten, että kokonaissyönti ja maitotuotos pysyvät halutulla tasolla. Syönti-indeksi antaa myös rehuntekijälle palautetta siitä, miten rehun teossa on onnistuttu suhteessa karjan tarpeisiin. Säilörehun syönti-indeksissä tarvittavat lähtötiedot määritetään Artturi-rehuanalyysissä ja väkirehujen osalta voidaan käyttää Rehutaulukoissa (MTT 2006) esitettyjä lähtötietoja. Syönti-indeksien laskemiseen on Artturi-verkkopalvelussa (www.mtt.fi/artturi) käytettävissä laskurit.

Rehuannoksen koostumuksen vaikutusten tunteminen lehmien vapaaehtoiseen syöntiin tekee mahdolliseksi lehmien ravintoaineiden saannin ja maidontuotannon mallintamisen ja mallien käytön ruokinnan optimoinnissa (ks. Huhtanen ym. 2008b). Kun rehuannoksen vaikutukset syöntiin on mallinnettu, on jatkotutkimuksissa mahdollista selvittää eläintekijöiden vaikutusta syöntiin.

\section{Kiitokset}

Kiitämme kaikkia kollegoita, erityisesti Terttu Heikkilää, jotka ovat antaneet käyttöömme aineistoja maidontuotantokokeista. Tutkimushanketta ovat MTT:n lisäksi rahoittaneet Suomen Akatemia, MMM, Valio Oy, Kemira GrowHow Oyj ja ProAgria Maaseutukeskusten liitto.

\section{Kirjallisuus}

Artturi, 2007. Artturi -verkkopalvelu. Viitattu 30.11.2007. Saatavilla: www.mtt.fi/artturi.

Huhtanen, P., Khalili, H., Nousiainen, J.I., Rinne, M., Jaakkola, S., Heikkilä, T. \& Nousiainen, J. 2002. Prediction of the relative intake potential of grass silage by dairy cows. Livestock Production Science 73: 111130.

Huhtanen, P., Nousiainen, J. \& Rinne, M. 2006. Recent developments in forage evaluation with special reference to practical applications. Agricultural and Food Science 15: 293-323.

Huhtanen, P., Rinne, M. \& Nousiainen, J. 2007a. Evaluation of the factors affecting silage intake of dairy cows: a revision of the relative silage dry-matter intake index. Animal 1: 758-770.

Huhtanen, P., Rinne, M. \& Nousiainen, J. 2007b. Evaluation of the concentrate factors affecting silage intake of dairy cows; Development of a relative total diet intake index. Submitted: Animal.

Huhtanen, P., Nousiainen, J. \& Rinne, M. 2008a. Karkearehujen sulavuuden määritys tarkentunut. Maataloustieteen Päivät 2008.

Huhtanen, P., Rinne, M. \& Nousiainen, J. 2008b. Lypsylehmien rehuannoksen taloudellinen optimointi tuotosvasteiden perusteella. Maataloustieteen Päivät 2008.

Kuoppala, K., Rinne, M., Nousiainen, J. \& Huhtanen, P. 2007. The effect of cutting time of grass silage in primary growth and regrowth and the interactions between silage quality and concentrate level on milk production of dairy cows. Livestock Science, in press.

Mertens, D.R. 1994. Regulation of forage intake. In Forage Quality, Evaluation and Utilization (ed GC Fahey Jr), pp. 450-493. American Society of Agronomy, Madison, WI, USA.

MTT, 2006. Rehutaulukot ja ruokintasuoistukset -verkkopalvelu. Saatavilla: www.agronet.fi/rehutaulukot.

Rinne, M., Jaakkola, S., Kaustell, K., Heikkilä, T. \& Huhtanen, P. 1999. Silages harvested at different stages of grass growth versus concentrate foods as energy and protein sources in milk production. Animal Science 69: 251-263.

Rinne, M., Nykänen, A., Kemppainen, J., Nyholm, L \& Nousiainen, J. 2008. Nurmikasvuston punaapilapitoisuuden voi ennustaa kalsiumpitoisuudesta. Maataloustieteen Päivät 2008. 